\title{
Petasin and isopetasin reduce CGRP release from trigeminal afferents indicating an inhibitory effect on TRPA 1 and TRPV1 receptor channels
}

\author{
Johanna Kleeberg-Hartmann, Birgit Vogler and Karl Messlinger *i]
}

\begin{abstract}
Background: Butterbur root extract with its active ingredients petasin and isopetasin has been used in the prophylactic treatment of migraine for years, while its sites of action are not completely clear. Calcitonin generelated peptide (CGRP) is known as a biomarker and promoting factor of migraine. We set out to investigate the impact of petasins on the CGRP release from trigeminal afferents induced by activation of the calcium conducting transient receptor potential channels (TRPs) of the subtypes TRPA1 and TRPV1.

Methods: We used well-established in vitro preparations, the hemisected rodent skull and dissected trigeminal ganglia, to examine the CGRP release from rat and mouse cranial dura mater and trigeminal ganglion neurons, respectively, after pre-incubation with petasin and isopetasin. Mustard oil and capsaicin were used to stimulate TRPA1 and TRPV1 receptor channels. CGRP concentrations were measured with a CGRP enzyme immunoassay.

Results: Pre-incubation with either petasin or isopetasin reduced mustard oil- and capsaicin-evoked CGRP release compared to vehicle in an approximately dose-dependent manner. These results were validated by additional experiments with mice expressing functionally deleted TRPA1 or TRPV1 receptor channels.

Conclusions: Earlier findings of TRPA1 receptor channels being involved in the site of action of petasin and isopetasin are confirmed. Furthermore, we suggest an important inhibitory effect on TRPV1 receptor channels and assume a cooperative action between the two TRP receptors. These mechanisms may contribute to the migraine prophylactic effect of petasins.
\end{abstract}

Keywords: Petasin, Isopetasin, Butterbur, CGRP, TRPA1, TRPV1, Migraine

\section{Background}

\section{Migraine and the trigeminovascular system}

Migraine is a complex neurological disorder characterized by a commonly unilateral, frequently severe headache, possibly preceded by an aura and accompanied by sensory and autonomic dysfunctions like photo- and phonophobia, nausea and vomiting [1-3]. While the

\footnotetext{
* Correspondence: karl.messlinger@fau.de

Institute of Physiology and Pathophysiology, Friedrich-Alexander-University of Erlangen-Nürnberg, Universitätsstraße 17, 91054 Erlangen, Germany
}

neurological and autonomic symptoms are thought to be mainly caused by central disturbances affecting also the central nociceptive pathways, the migraine headache is believed to depend fundamentally on the activation and sensitization of the trigeminovascular system, which consists of trigeminal afferents innervating intracranial arterial blood vessels [4-7]. Activation of trigeminal afferents, in particular meningeal afferents innervating the dura mater, is very likely responsible for the activation

C C The Author(s). 2021 Open Access This article is licensed under a Creative Commons Attribution 4.0 International License, which permits use, sharing, adaptation, distribution and reproduction in any medium or format, as long as you give appropriate credit to the original author(s) and the source, provide a link to the Creative Commons licence, and indicate if changes were made. The images or other third party material in this article are included in the article's Creative Commons licence, unless indicated otherwise in a credit line to the material. If material is not included in the article's Creative Commons licence and your intended use is not permitted by statutory regulation or exceeds the permitted use, you will need to obtain permission directly from the copyright holder. To view a copy of this licence, visit http://creativecommons.org/licenses/by/4.0/ The Creative Commons Public Domain Dedication waiver (http://creativecommons.org/publicdomain/zero/1.0/) applies to the data made available in this article, unless otherwise stated in a credit line to the data. 
of central pain pathways and finally for the generation of migraine pain $[8,9]$.

\section{Role for TRP receptors in trigeminal nociception}

Transient receptor potential (TRP) channels play an important role in the transduction of cell signals and thus also in trigeminal nociception. Transient receptor potential vanilloid type 1 (TRPV1) receptor channels detect heat and are activated or sensitized by chemical stimuli (e.g. capsaicin and extracellular protons). TRPV1 receptor channels are expressed by the majority of nociceptive trigeminal afferents, mostly C-fiber but also a minority of $\mathrm{A} \delta$ fiber afferents. Interestingly, $70 \%$ of CGRPimmunoreactive neurons were found to be colocalized with TRPV1 channels [10, 11].

Transient receptor potential ankyrin type 1 (TRPA1) receptor channels are nearly exclusively expressed by Cfibers. They are activated by multiple exogenous chemical agents (e.g. isothiocyanates, acrolein and formalin) and endogenous inflammatory stimuli (e.g. bradykinin). Many TRPA1-positive neurons co-express TRPV1 channels and can be sensitized or activated by an increase in intracellular calcium, i.e. also by activation of calcium conducting TRPV1 receptor channels [12-14]. Some experimental evidence exists for either a cooperative effect between TRPV1 and TRPA1 receptor channels [15], an TRPV1-inhibiting effect of TRPA1 [16], or an ambiguous role of the TRPA1 channel as both an activator [17] and an inhibitor of spinal trigeminal neurons [18].

\section{What is the link of petasins and CGRP in migraine?}

Due to the high prevalence and the severe symptom burden, the pathophysiology and therapy of migraine have been subject of research for decades $[3,6,8,19]$. An effective phytotherapeutical option in migraine prophylaxis is an extract from the rhizome of the plant butterbur (Petasites hybridus). Butterbur root extract with its active ingredients petasin and isopetasin (petasins) has been used in migraine prophylaxis for many years [20-22]. However, the site of action is still not clear. Among the different effects that are attributed to petasins in the trigeminovascular system, their presumed inhibitory effect on the release of neuropeptides, especially calcitonin gene-related peptide (CGRP), is of particular relevance. CGRP is released from activated trigeminal afferents. Trigeminal afferent nerve fibers of the cranial dura mater [23], of pial and intracerebral blood vessels [24] and of the trigeminal ganglion [25, 26] are peripheral sites of CGRP release, while the central source of CGRP are fibers of the spinal trigeminal nucleus [27]. The highest concentration of CGRP is found in the trigeminal ganglion [28] in which $48 \%$ of the neurons have been found CGRP-immunopositive [26]. Upon activation of primary afferents, CGRP is released by
$\mathrm{Ca}^{2+}$-dependent exocytotic mechanisms [29]. When released in pathological concentrations, CGRP can likely act as nociceptive mediator possibly contributing to the initiation and continuance of nociceptive events [30, 31].

Previous preclinical experiments have shown that CGRP release from central afferent terminals in a mouse spinal cord in vitro preparation is reduced by isopetasin [32]. Also, CGRP secretion from neuroendocrine CA77 cells was reduced by $1 \mu \mathrm{MS}$-petasin, a constituent of butterbur extract, which inhibited also calcium influx [33]. Therefore, it is of considerable interest to know if and by which mechanisms petasins may be able to reduce the stimulated CGRP release from trigeminal afferents innervating the trigeminovascular system, particularly the cranial dura mater.

\section{Petasins - a therapeutic option in migraine prophylaxis, but how does it work?}

Common butterbur (Petasites hybridus), domestic in Europe and north western Asia, belongs to the Asteracae and has been used for centuries in folk medicine for the treatment of many different symptoms like spastic pain, dysmenorrhea, cough, and wound healing [34]. Since the 1950s, medical interest in butterbur has newly grown. Its spasmolytic effects in the gastrointestinal [35] and the urinary tract [36], and anti-inflammatory activity in allergic rhinitis and asthma have been subjects of medical research [37-39]. A further therapeutic option for the use of the extract from the plant's rhizome is prophylactic migraine treatment [20-22].

The extract contains several compounds, of which two active agents, the sesquiterpenes petasin and isopetasin, are considered effective in the prevention of migraine pain [40]. Petasin is not stable but converts to its isomer isopetasin spontaneously. Therefore, it is not clear which of the components contributes to which degree to the therapeutic effects [32]. Although butterbur root extract has been used successfully in prophylactic migraine therapy for several years, little is known about the site and mode of action of the petasins. Thomet et al. [41] discussed antiinflammatory effects through inhibition of leukotriene synthesis and the activity of eosinophils, while Wang et al. [42-44] hypothesized that petasins act as a direct antagonist of voltage-gated $\mathrm{Ca}^{2+}$-channels (VGCCs) in vascular smooth muscle cells. Blockade of VGCCs could also be found by Horak et al. [45]. Ko et al. [46], too, confirmed the impact of petasins on VGCCs and furthermore supposed that the relaxing effect of petasins is also due to an antimuscarinic action. However, the relevance of these mechanisms for migraine therapy is doubtful. Benemei et al. [32] using calcium imaging and patch clamp recordings found that isopetasin activates TRPA1 channels leading to excitation of neuropeptide containing nociceptors, which 
finally results in heterologous desensitization and reduced neurogenic inflammation. They proposed that this mechanism may account for the anti-migraine action of butterbur.

Our hypothesis underlying the present preclinical experiments was that petasins and isopetasin reduce the stimulated CGRP release from meningeal afferents and trigeminal ganglia, which may indicate desensitization of TRPV1 or TRPA1 receptor channels.

\section{Methods}

All experiments and procedures were carried out according to the German guidelines and regulations of the care and treatment of laboratory animals and the European Communities Council Directive of November 24, 1986 (86/609/EEC), amended September 22, 2010 (2010/63/EU).

For CGRP release experiments from the dura mater and trigeminal ganglia, home bred adult Wistar rats of both sexes $(260-410 \mathrm{~g})$ as well as adult C57 BL/6 mice of both sexes and different genetic configuration were used: C57 BL/6 wild type mice (18-31 g), C57 BL/6 knock out mice with functionally deleted TRPA1 (18$30 \mathrm{~g})$ or deleted TRPV1 (19-31 g) receptor channels. Animals were euthanized by $\mathrm{CO}_{2}$ inhalation and decapitated. Rat skulls were freed from skin, muscles, eyes and mandibles, and sagittally divided into two halves. The brain was carefully removed taking care not to damage the dura mater lining the skull. Trigeminal ganglia (TGs) were dissected together with their dura sheath by cutting the trigeminal branches, the ophthalmic, maxillary and mandibular nerves at their utmost distal sites accessible, and kept in wells of a microplate filled with $120 \mu \mathrm{L}$ of synthetic interstitial fluid (SIF). The microplate was placed on the surface of a pre-warmed water bath $\left(37^{\circ} \mathrm{C}\right)$. Mice skulls were flayed and sagittally divided into two halves. Mice brains were carefully removed from the skull. One of the mice skull halves of each animal was used for dura release experiments, while from the other half the TG was dissected and processed like rat TGs. Skull halves for dura experiments were washed in gently flowing SIF for $30 \mathrm{~min}$ at room temperature and subsequently mounted upon the surface of a water bath of $37^{\circ} \mathrm{C}$ with the opening upside. Mice skull halves were sealed with a rim of Vaseline ${ }^{\circ}$ on their outer surface in order to avoid spillage due to hairline cracks in the filigree mouse skull, and mounted accordingly. Skull cavities were filled with $500 \mu \mathrm{L}$ (rat) or $200 \mu \mathrm{L}$ (mouse) of SIF. The same volumes were used for pre-incubating solutions for $1 \mathrm{~h}$ as well as for the respective incubating steps of 5 min each during CGRP release experiments. Evaporation during pre-incubation was prevented by a self-adhesive plastic film attached on top of the water bath containers.
All tissue samples were incubated with either butterbur root extract solved in ethanol containing different concentrations of petasins $(3 \mu \mathrm{g} / \mathrm{mL}, 10 \mu \mathrm{g} / \mathrm{mL}, \quad 30 \mu \mathrm{g} / \mathrm{mL}$, $100 \mu \mathrm{g} / \mathrm{mL})$, isopetasin solved in ethanol $(3 \mu \mathrm{g} / \mathrm{mL}, 10 \mu \mathrm{g} /$ $\mathrm{mL}, 30 \mu \mathrm{g} / \mathrm{mL}$ ) or ethanol equivalent to the respective concentration of petasins or isopetasin $(0.0316 \%, 0.105 \%$, $0.316 \%, 1.055 \%$ ethanol) for $1 \mathrm{~h}$ and subsequently washed with SIF three times, before fluid samples were sampled for measurements of CGRP concentration using a pipette without touching the tissues. The first two samples were taken after incubation with SIF for 5 min each in order to measure the basal CGRP release from the dura mater and the trigeminal ganglia. Then the TRPA1 receptor agonist allylisothiocyanate (mustard oil, MO) $5 \times 10^{-4} \mathrm{M}$ (Wistar, C57 BL/6 wild type, C57 BL/6 TRPA1 knock-out) or the TRPV1 receptor agonist capsaicin (Caps) $5 \times 10^{-7} \mathrm{M}$ in SIF (C57 BL/6 TRPV1 knock-out) was applied and incubated for $5 \mathrm{~min}$, followed by one $5 \mathrm{~min}$ application of SIF. Finally, caps $5 \times 10^{-7} \mathrm{M}$ in SIF (Wistar, C57 BL/6 wild type, C57 BL/6 TRPA1 knock-out), or MO $5 \times 10^{-4} \mathrm{M}$ (C57 BL/6 TRPV1 knock-out) was applied for incubation of $5 \mathrm{~min}$. After each incubation step the fluid was carefully removed and SIF was added for washing the tissues, before the next solution was added. From each sample $100 \mu \mathrm{l}$ were collected in Eppendorf cups, diluted with $25 \mu \mathrm{L}$ EIA buffer (Bertin Pharma, France) containing peptidase inhibitors, and stored on ice or deep-frozen until they were processed for CGRP measurement.

CGRP was measured using a CGRP enzyme immunoassay (EIA) kit (Bertin Pharma/SPIbio, Montigny Le Bretonneux, France) according to the manufacturer's instruction. The sandwich technique of this assay consists of immune reactions of capture and tracer antibodies recognizing different CGRP epitopes, and the enzymatic activity of acetylcholinesterase (AChE, Ellman's reagent). The emitted light is subsequently spectrophotometrically detected as a measure for the CGRP concentration in the samples, displayed as $\mathrm{pg} / \mathrm{mL}$. The detection limit of the assay is $5 \mathrm{pg} / \mathrm{mL}$ according to the manufacturer's information.

Statistical analysis was performed with STATISTICA (StatSoft 7.0, Tulsa, OK). The consecutive measurements at intervals of $5 \mathrm{~min}$ were analysed with repeated measures ANOVA and least square difference (LSD) posthoc test on the basis of the raw data. Comparisons between different concentrations and groups were analysed by univariate ANOVA and least square difference (LSD) post-hoc test on the basis of data normalized to the mean of the two initial CGRP measurements after SIF application in each experiment to compensate for interassay variations. Data are presented as means \pm SEM, $p<0.05$ was considered statistically significant. Panels were created with Origin $^{\circ} 2019$ (OriginLab, Massachusetts). 
Chemicals: Synthetic interstitial fluid (SIF) is composed of (in mM): $107.8 \mathrm{NaCl}, 26.2 \mathrm{NaHCO}_{3}, 9.64 \mathrm{Na}$ gluconate, 7.6 sucrose, 5.55 glucose, $3.5 \mathrm{KCl}, 1.67$ $\mathrm{NaH}_{2} \mathrm{PO}_{4} \times 2 \quad \mathrm{H}_{2} \mathrm{O} \quad 1.53 \quad \mathrm{CaCl}_{2} \times 2 \quad \mathrm{H}_{2} \mathrm{O}$ and 0.69 $\mathrm{MgSO}_{4} \times 7 \mathrm{H}_{2} \mathrm{O}$, adjusted to $\mathrm{pH}$ 7.4. Butterbur root extract (Petadolex ${ }^{\circ}$, Weber \& Weber, Inning/Ammersee, Germany) was dissolved in ethanol at a concentration of $9.483 \mathrm{mg} / \mathrm{mL}$ and step-wise diluted with SIF to the applied concentrations of 100, 30, 10 and $3 \mu \mathrm{g} / \mathrm{mL}$. Isopetasin (HWI Group, Rülzheim, Germany) was correspondingly dissolved in ethanol and diluted with SIF to the respective concentrations. Accordingly, ethanol concentrations in the vehicle solutions tested were $10.55,3.16,1.05$ and $0.315 \mu \mathrm{L} / \mathrm{mL}$ in SIF. Mustard oil (MO) (Merck, Darmstadt, Germany) and capsaicin (Caps) (Sigma-Aldrich, Taufkirchen, Germany) were dissolved in ethanol $1 \%$ and diluted with SIF to the final concentrations of $5 \times 10^{-4} \mathrm{M}(\mathrm{MO})$ and $5 \times 10^{-7} \mathrm{M}$ (Caps).

\section{Results}

\section{Butterbur root extract, Wistar}

The effect of pre-incubation with butterbur root extract solved in ethanol was tested in the range of $3-100 \mu \mathrm{g} /$ $\mathrm{mL}$ (concentration of petasins in the extract: $3 \mu \mathrm{g} / \mathrm{mL}$, $10 \mu \mathrm{g} / \mathrm{mL}, 30 \mu \mathrm{g} / \mathrm{mL}, 100 \mu \mathrm{g} / \mathrm{mL}$ ) and also compared to pre-incubation with the solvent ethanol in the respective concentrations $(0.0316 \%, 0.105 \%, 0.316 \%, 1.055 \%$ ethanol). Raw data was used for repeated measures analysis, while normalized data was used for comparison between ethanol and petasins.

\section{Dura mater, basal CGRP release}

After $1 \mathrm{~h}$ treatment of the hemisected skulls with different concentrations of the vehicle (SIF) containing ethanol (0.0316-1.055\%), the CGRP concentration in the initial SIF solutions (basal release) varied between 4.4 and $25.3 \mathrm{pg} / \mathrm{mL}$, which is mainly due to the inter-assay variation of the EIA kits. However, since there was no correlation of the basal release with the ethanol concentrations, and the blank values of SIF $(6.7-10.3 \mathrm{pg} / \mathrm{mL})$ were also in this range, there was no reason to assume that ethanol at these concentrations caused CGRP release itself. Therefore, the release values of all vehicle experiments $(n=12)$ were averaged and compared with the release values following $1 \mathrm{~h}$ treatment with different concentrations of petasins $(3-100 \mu \mathrm{g} / \mathrm{mL})$. There was also no evidence for a CGRP release stimulating effect of the petasins or isopetasin; basal values after SIF varied between 12.7 and $21.3 \mathrm{pg} / \mathrm{mL}$ without any correlation to the doses used; blank values were $8.5-10.8 \mathrm{pg} / \mathrm{mL}$. Raw data with deviations are displayed in Tables 1, 2, 3 .

For all concentrations of petasins in butterbur root extract and ethanol without extract, the basal CGRP release from the dura mater encephali within 5 min was $15.5 \pm 1.3 \mathrm{pg} / \mathrm{mL}(n=36)$.

\section{Dura mater, stimulated CGRP release}

Stimulation with the TRPA1 receptor $\mathrm{MO}$ as well as with the TRPV1 receptor agonist Caps increased CGRP release significantly after ethanol incubation and after all concentrations of petasins but $100 \mu \mathrm{g} / \mathrm{mL}$ (Tables 1 and 2). However, a CGRP reducing effect of pre-incubation with butterbur root extract could be observed for all concentrations compared to the vehicle (ethanol), where the CGRP release after MO was 11.2-fold and after Caps 22.4-fold of the basal release. Nevertheless, there was no strict dose-dependent suppression of the CGRP release after 3,10 and $30 \mu \mathrm{g} / \mathrm{mL}$ petasins (Fig. 1a), resulting in a MO-stimulated CGRP release of 4.5-, 5.6- and 3.7-fold, respectively, and a Caps-stimulated release of 7.9-fold, 12.2-fold and 9.1-fold, respectively, compared to the basal release. Significant differences between the serial samples (raw data, $\mathrm{F}_{4,124}=104.82, p<0.0001$ ) and between the vehicle and the petasin doses (normalized data, $\mathrm{F}_{4,31}=5.63, p=0.0016$ ) were indicated by two-way repeated measures ANOVA. LSD post hoc test revealed differences between the respective ethanol and petasin doses after stimulation steps (MO: $3 \mu \mathrm{g} / \mathrm{mL}: p=0.098$; $10 \mu \mathrm{g} / \mathrm{mL}: p=0.169 ; 30 \mu \mathrm{g} / \mathrm{mL}: p=0.067 ; 100 \mu \mathrm{g} / \mathrm{mL}:$ $p=0.018$, LSD, $n=6$ for each concentration; Caps: $3 \mu \mathrm{g} /$ $\mathrm{mL}: p=0.0009 ; 10 \mu \mathrm{g} / \mathrm{mL}: p=0.015 ; 30 \mu \mathrm{g} / \mathrm{mL}: p=$ $0.002 ; 100 \mu \mathrm{g} / \mathrm{mL}: p<0.0001$; LSD, $n=6$ for each concentration).

\section{Trigeminal ganglion, basal CGRP release}

After $1 \mathrm{~h}$ incubation of trigeminal ganglia with different concentrations of the vehicle (SIF) containing ethanol (0.0316-1.055\%), the CGRP concentration in the initial SIF solutions (basal release) varied between 23.2 and $49.3 \mathrm{pg} / \mathrm{mL}$, which is mainly due to the inter-assay variation of the EIA kits. However, since there was no correlation of the basal release with the ethanol concentrations, likewise, there was no reason to assume that ethanol at these concentrations caused CGRP release itself. Therefore, the release values of all vehicle experiments $(n=12)$ were averaged and compared with the release values following $1 \mathrm{~h}$ treatment with different concentrations of petasins $(3-100 \mu \mathrm{g} / \mathrm{mL})$. There was also no evidence for a CGRP release stimulating effect of the petasins or isopetasin; basal values after SIF varied between 27.2 and $75.8 \mathrm{pg} / \mathrm{mL}$ without any correlation to the doses used. Raw data with deviations are displayed in Tables 4, 5, 6 .

For all concentrations of petasins in butterbur root extract $(3 \mu \mathrm{g} / \mathrm{mL}, 10 \mu \mathrm{g} / \mathrm{mL}, 30 \mu \mathrm{g} / \mathrm{mL}, 100 \mu \mathrm{g} / \mathrm{mL})$ and the solvent ethanol without extract, the basal CGRP release from TG within $5 \mathrm{~min}$ was $41.5 \pm 6.8 \mathrm{pg} / \mathrm{mL}(n=36)$. 
Table 1 Dura mater encephali, different ethanol concentrations. CGRP release in $\mathrm{pg} / \mathrm{ml}$, all values are means $\pm \mathrm{SEM},{ }^{*} p<0.05$

\begin{tabular}{lcccccc}
\hline \multicolumn{7}{c}{ Ethanol concentration in SIF } \\
& $0.0316 \%$ & $0.105 \%$ & $0.316 \%$ & $1,055 \%$ & total & $p$ (serial samples, total) \\
\hline $\mathrm{n}$ & 4 & 2 & 2 & 4 & 12 & \\
\hline SIF & $7.9 \pm 1.2$ & $25.2 \pm 1.8$ & $19.9 \pm 0.2$ & $4.4 \pm 0.5$ & $14.4 \pm 0.9$ & \\
SIF & $9.3 \pm 2.3$ & $23.4 \pm 2.6$ & $21.8 \pm 1.3$ & $6.2 \pm 0.9$ & $15.2 \pm 1.8$ & 0.920 \\
MO $5 \times 10^{-4} \mathrm{M}$ & $96.4 \pm 18.1^{*}$ & $138.5 \pm 1.2^{*}$ & $123.5 \pm 43.8$ & $77.3 \pm 6.3$ & $108,9 \pm 17.4^{*}$ & $<0.001$ \\
SIF & $79.1 \pm 6.0$ & $98.2 \pm 9.4$ & $93.9 \pm 4.0$ & $72.2 \pm 7.8$ & $85.8 \pm 6.8$ & 0.077 \\
Caps $5 \times 10^{-7} \mathrm{M}$ & $185.5 \pm 20.1^{*}$ & $126.8 \pm 22.8$ & $120.6 \pm 7.3$ & $167.6 \pm 19.8^{*}$ & $150,1 \pm 17.5^{*}$ & $<0.001$ \\
\hline
\end{tabular}

Trigeminal ganglion, stimulated CGRP release

Stimulation with the TRPA1 receptor agonist MO increased CGRP release significantly for all concentrations of petasins. Pre-incubation with a concentration of $100 \mu \mathrm{g} / \mathrm{mL}$ petasins contained in butterbur root extract was the only concentration which was not followed by a significantly increased CGRP release after stimulation with the TRPV1 receptor agonist Caps (Tables 4 and 5). However, a CGRP-reducing effect of pre-incubation with butterbur root extract could be observed for all concentrations compared to the vehicle (ethanol), where the CGRP release after MO was 8.7-fold and after Caps 12.7-fold of the basal release. Nevertheless, there was no strict dose-dependent suppression of the CGRP release with almost similar normalized values after 3, 10 and $30 \mu \mathrm{g} / \mathrm{mL}$ petasins (Fig. 1b), resulting in a MOstimulated CGRP release of 5.6-, 5.9- and 6.1-fold, respectively, and a Caps-stimulated CGRP release of 4.8-, 8.8- and 9.3-fold, respectively, compared to the basal release. Significant differences between the serial samples (raw data, $\mathrm{F}_{4,124}=72.75, p<0.0001$ ) and between the vehicle and the petasin doses (normalized data, $\mathrm{F}_{4,31}=$ $10.26, p<0.0001$ ) were indicated by two-way repeated measures ANOVA. LSD post hoc test revealed differences between the respective ethanol and petasin doses after stimulation steps (MO: $3 \mu \mathrm{g} / \mathrm{mL}: p=0.022 ; 10 \mu \mathrm{g} / \mathrm{mL}$ : $p=0.036 ; 30 \mu \mathrm{g} / \mathrm{mL}: p=0.053 ; 100 \mu \mathrm{g} / \mathrm{mL}: p=0.0008$; LSD, $n=6$ for each concentration; Caps: $3 \mu \mathrm{g} / \mathrm{mL}$ : $p<0.0001 ; 10 \mu \mathrm{g} / \mathrm{mL}: p=0.005 ; 30 \mu \mathrm{g} / \mathrm{mL}: p=0.012$; $100 \mu \mathrm{g} / \mathrm{mL}: p<0.0001$; LSD, $n=6$ for each concentration).

\section{Isopetasin, Wistar}

The effect of pre-incubation with isopetasin solved in ethanol on the CGRP release was tested in the range of $3-30 \mu \mathrm{g} / \mathrm{mL}(3 \mu \mathrm{g} / \mathrm{mL}, 10 \mu \mathrm{g} / \mathrm{mL}, 30 \mu \mathrm{g} / \mathrm{mL})$, and will later be compared to the effect of the same concentrations of petasins $(3 \mu \mathrm{g} / \mathrm{mL}, 10 \mu \mathrm{g} / \mathrm{mL}, 30 \mu \mathrm{g} / \mathrm{mL})$ included in the extract as described earlier. Raw data (see Tables 3, 6) was used for repeated measures analysis while normalized data was used for comparison between ethanol and isopetasin doses.

\section{Dura mater, basal CGRP release}

After pre-incubation with all concentrations of isopeta$\sin (3 \mu \mathrm{g} / \mathrm{mL}, 10 \mu \mathrm{g} / \mathrm{mL}, 30 \mu \mathrm{g} / \mathrm{mL})$, the basal CGRP release from the dura mater encephali within $5 \mathrm{~min}$ was $16.9 \pm 1.8 \mathrm{pg} / \mathrm{mL}(n=18)$.

\section{Dura mater, stimulated CGRP release}

Significant differences between the serial samples (raw data, $\mathrm{F}_{4,104}=155.78 p<0.0001$ ), and between the vehicle and the isopetasin doses $\left(\mathrm{F}_{3,26}=3.18, p=0.04\right)$ were observed by two-way repeated measures ANOVA. Stimulation with the TRPA1 receptor agonist $M O$ and the TRPV1 receptor agonist Caps increased CGRP release for all concentrations of isopetasin.

Even though most CGRP levels were elevated after stimulation steps, a reduction of the released CGRP compared to ethanol as well as significant differences between vehicle and 10 and $30 \mu \mathrm{g} / \mathrm{mL}$ isopetasin after stimulation with TRPV1 agonist capsaicin were observed

Table 2 Dura mater encephali, different petasin concentrations. CGRP release in $\mathrm{pg} / \mathrm{ml}$, all values are means \pm SEM, ${ }^{*} p<0.05$

\begin{tabular}{|c|c|c|c|c|c|c|c|c|}
\hline & \multicolumn{8}{|c|}{ Concentration of petasins in butterbur root extract } \\
\hline & $3.0 \mu \mathrm{g} / \mathrm{ml}$ & $\mathrm{p}$ (serial samples) & $10 \mu \mathrm{g} / \mathrm{ml}$ & p (serial samples) & $30 \mu \mathrm{g} / \mathrm{ml}$ & $\mathrm{p}$ (serial samples) & $100 \mu \mathrm{g} / \mathrm{ml}$ & $\mathrm{p}$ (serial samples) \\
\hline $\mathrm{n}$ & 6 & & 6 & & 6 & & & \\
\hline SIF & $21.3 \pm 1.9$ & & $13.2 \pm 1.3$ & & $13.1 \pm 0.9$ & & $17.6 \pm 1.3$ & \\
\hline SIF & $21.0 \pm 2.2$ & 0.983 & $13.0 \pm 1.0$ & 0.985 & $12.7 \pm 0.9$ & 0.977 & $17.6 \pm 1.1$ & 0.996 \\
\hline MO $5 \times 10^{-4} \mathrm{M}$ & $91.3 \pm 11.8^{*}$ & $<0.001$ & $76.9 \pm 14.9 *$ & $<0.001$ & $47.7 \pm 6.6^{*}$ & 0.023 & $23.0 \pm 1.7$ & 0.721 \\
\hline SIF & $96.0 \pm 9.9$ & 0.760 & $100.3 \pm 13.7$ & 0.126 & $51.2 \pm 6.2$ & 0.816 & $24.6 \pm 1.4$ & 0.916 \\
\hline Caps $5 \times 10^{-7} \mathrm{M}$ & $161.2 \pm 20.4^{*}$ & $<0.001$ & $151.5 \pm 25.5^{*}$ & $<0.001$ & $114.2 \pm 10.5^{*}$ & $<0.001$ & $50.6 \pm 6.2$ & 0.088 \\
\hline
\end{tabular}


Table 3 Dura mater encephali, different isopetasin concentrations. CGRP release in $\mathrm{pg} / \mathrm{ml}$, all values are means \pm SEM, ${ }^{*} p<0.05$

\begin{tabular}{|c|c|c|c|c|c|c|}
\hline & \multicolumn{6}{|c|}{ Isopetasin concentration } \\
\hline & $3.0 \mu \mathrm{g} / \mathrm{ml}$ & p (serial samples) & $10 \mu \mathrm{g} / \mathrm{ml}$ & $\mathrm{p}$ (serial samples) & $30 \mu \mathrm{g} / \mathrm{ml}$ & p (serial samples) \\
\hline $\mathrm{n}$ & 6 & & 6 & & 6 & \\
\hline SIF & $19.6 \pm 1.8$ & & $14.2 \pm 1.2$ & & $17.2 \pm 2.1$ & \\
\hline SIF & $19.1 \pm 1.7$ & 0.976 & $13.7 \pm 1.8$ & 0.979 & $17.3 \pm 2.4$ & 0.996 \\
\hline $\mathrm{MO} 5 \times 10^{-4} \mathrm{M}$ & $104.1 \pm 8.6^{*}$ & $<0.001$ & $48.8 \pm 9.6$ & 0.060 & $90.1 \pm 29.0 *$ & $<0.001$ \\
\hline SIF & $76.9 \pm 12.1$ & 0.144 & $62.7 \pm 11.0$ & 0.456 & $74.1 \pm 14.5$ & 0.387 \\
\hline Caps $5 \times 10^{-7} \mathrm{M}$ & $346.4 \pm 17.6$ & $<0.001$ & $172.7 \pm 21.5^{*}$ & $<0.001$ & $129.1 \pm 19.3^{*}$ & 0.004 \\
\hline
\end{tabular}

(MO: $3 \mu \mathrm{g} / \mathrm{mL}: p=0.193 ; 10 \mu \mathrm{g} / \mathrm{mL}: p=0.085 ; 30 \mu \mathrm{g}$ / $\mathrm{mL}: p=0.133$; LSD, $n=6$ for each concentration; Caps: $3 \mu \mathrm{g} / \mathrm{mL}: p=0.377 ; 10 \mu \mathrm{g} / \mathrm{mL}: p=0.047 ; 30 \mu \mathrm{g} / \mathrm{mL}: p=$ 0.004; LSD, $n=6$ for each concentration).

\section{Trigeminal ganglion, basal CGRP release}

After pre-incubation with all concentrations of isopeta$\sin (3 \mu \mathrm{g} / \mathrm{mL}, 10 \mu \mathrm{g} / \mathrm{mL}, 30 \mu \mathrm{g} / \mathrm{mL})$, the basal CGRP release from trigeminal ganglia within $5 \mathrm{~min}$ was $41.4 \pm$ $7.7 \mathrm{pg} / \mathrm{mL}(n=18)$.

\section{Stimulated CGRP release}

Significant differences between the serial samples $\left(\mathrm{F}_{4,100}=101.22 p<0.0001\right)$ were revealed by two-way repeated measures ANOVA, while there was no significant effect between vehicle and the isopetasin doses $\left(\mathrm{F}_{3,25}=\right.$ 1.41, $p=0.263)$. In detail, stimulation with the TRPA1 receptor agonist $\mathrm{MO}$ as well as the TRPV1 receptor agonist Caps increased CGRP for all concentrations of isopetasin (Fig. 2b).

Even though most CGRP levels were elevated after the stimulation steps, a slight reduction of the CGRP released from trigeminal ganglia compared to ethanol was observed for isopetasin. Furthermore, a significant reduction of CGRP release between ethanol and $30 \mu \mathrm{g} / \mathrm{mL}$ isopetasin after stimulation with TRPV1 agonist capsaicin was detected (MO: $3 \mu \mathrm{g} / \mathrm{mL}: p=$ $0.86 ; 10 \mu \mathrm{g} / \mathrm{mL}: p=0.507 ; 30 \mu \mathrm{g} / \mathrm{mL}: p=0.205 ; \mathrm{LSD}$, $n=6$ for each concentration; Caps: $3 \mu \mathrm{g} / \mathrm{mL}: p=$ $0.227, n=6 ; 10 \mu \mathrm{g} / \mathrm{mL}: p=0.306, n=5 ; 30 \mu \mathrm{g} / \mathrm{mL}$ : $p=0.01, n=6$; LSD).

\section{Effect of petasins in butterbur root extract compared to isopetasin}

The effect of pre-incubation with petasins $(3 \mu \mathrm{g} / \mathrm{mL}$, $10 \mu \mathrm{g} / \mathrm{mL}, 30 \mu \mathrm{g} / \mathrm{mL}$ ) contained in butterbur root extract and solved in ethanol on the CGRP release from dura mater encephali and trigeminal ganglia was compared to the effect of the same concentration of isopetasin $(3 \mu \mathrm{g} /$ $\mathrm{mL}, 10 \mu \mathrm{g} / \mathrm{mL}, 30 \mu \mathrm{g} / \mathrm{mL}$ ) solved in ethanol on the basis of normalized data. Normalized data of the relative increase of CGRP after stimulation with MO or Caps are displayed in Tables 7 and 8.

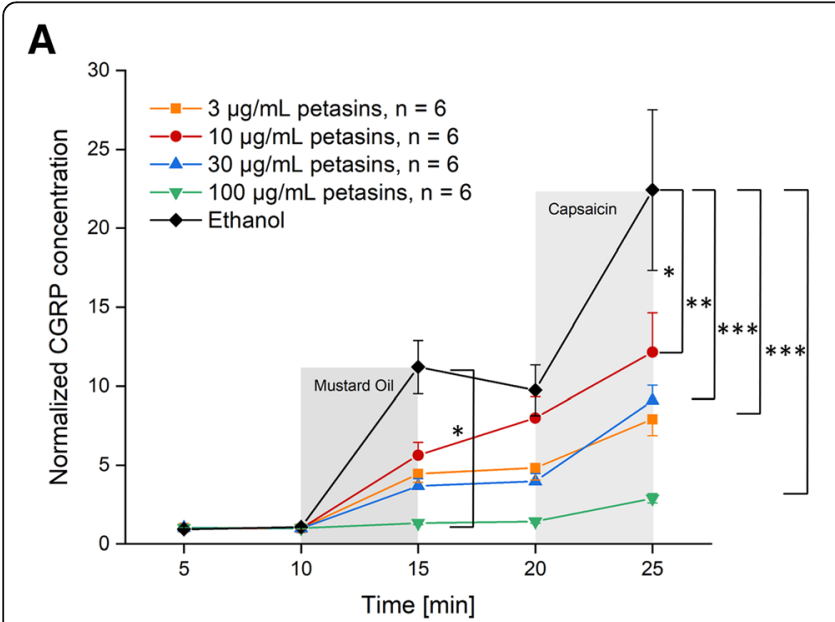

B

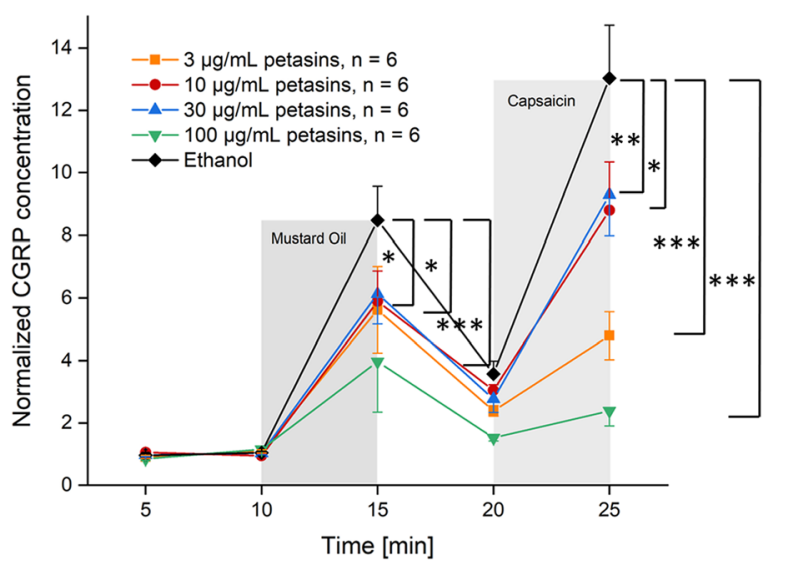

Fig. 1 a Dura mater, rat. b Trigeminal ganglion, rat. Normalized CGRP release after pre-incubation with butterbur root extract (petasin concentrations 3, 10, 30, $100 \mu \mathrm{g} / \mathrm{mL}, n=6$ each) compared to pre-incubation with the vehicle ethanol $(n=12)$ for 1 h. Stimulation steps with $5 \times$ $10^{-4} \mathrm{M}$ mustard oil (minutes 10-15 min) or $5 \times 10^{-7} \mathrm{M}$ capsaicin (minutes 20-25); other steps with SIF incubation (minutes 5-10 and 15-20); ${ }^{*} p<0.05,{ }^{* *} p<0.01,{ }^{* *} p<0.001$ 
Table 4 Trigeminal ganglia, different ethanol concentrations. CGRP release in $\mathrm{pg} / \mathrm{ml}$, all values are means $\pm \mathrm{SEM},{ }^{*} p<0.05$

\begin{tabular}{lcccccc}
\hline \multicolumn{7}{c}{ Ethanol concentration in SIF } \\
& $0.0316 \%$ & $0.105 \%$ & $0.316 \%$ & $1,055 \%$ & total & $p$ (serial samples, total) \\
\hline $\mathrm{n}$ & 4 & 2 & 2 & 4 & 12 & \\
\hline SIF & $43.1 \pm 8.0$ & $45.0 \pm 7.0$ & $43.9 \pm 3.0$ & $23.2 \pm 2.2$ & $38.8 \pm 5.1$ & 0.965 \\
SIF & $42.6 \pm 5.8$ & $39.3 \pm 5.5$ & $49.3 \pm 7.9$ & $28.0 \pm 4.7$ & $39.8 \pm 6.0$ & $<0.001$ \\
MO $5 \times 10^{-4} \mathrm{M}$ & $291.5 \pm 34.1^{*}$ & $401.3 \pm 68.0^{*}$ & $410.7 \pm 53.8^{*}$ & $253.7 \pm 49.0^{*} 339.3 \pm 51.2^{*}$ & $<0.001$ \\
SIF & $128.4 \pm 10.9^{*}$ & $139.0 \pm 17.9^{*}$ & $151.1 \pm 15.9^{*}$ & $95.4 \pm 9.4^{*}$ & $128.5 \pm 13.5^{*}$ & $<0.001$ \\
Caps $5 \times 10^{-7} \mathrm{M}$ & $407.9 \pm 25.1^{*}$ & $480.9 \pm 119.2^{*}$ & $600.1 \pm 45.2^{*}$ & $381.9 \pm 23.5^{*} 467.7 \pm 53.3^{*}$ & $<$ \\
\hline
\end{tabular}

\section{Dura mater}

Effects on the CGRP release from the dura mater encephali were compared after stimulating steps with $\mathrm{MO}$ and Caps. Univariate ANOVA did not indicate significant differences after stimulation with $\mathrm{MO}$ between the petasin and isopetasin group (normalized data, $\mathrm{F}_{1,30}=$ $0.03, p=0.87)$ as well as the respective concentrations (normalized data, $\mathrm{F}_{2,30}=0.64, p=0.53$ ). The LSD post hoc test revealed that stimulation with $\mathrm{MO}$ did not cause significant differences between the respective doses of the petasin and isopetasin group $(3 \mu \mathrm{g} / \mathrm{mL}: p=$ $0.351 ; 10 \mu \mathrm{g} / \mathrm{mL}: p=0.052 ; 30 \mu \mathrm{g} / \mathrm{mL}: p=0.432 ; n=6$ for each concentration, LSD). However, for Caps stimulation, univariate ANOVA indicated significant differences between the petasin and isopetasin group (normalized data, $\mathrm{F}_{1,30}=5.67, p=0.02$ ) but not between the respective concentrations (normalized data, $\mathrm{F}_{2,30}=$ 2.96, $p=0.07$ ). According to LSD post hoc test, stimulation with Caps caused significant differences for the concentration $3 \mu \mathrm{g} / \mathrm{mL} \quad(p=0.0006, n=6$, LSD; $10 \mu \mathrm{g} / \mathrm{mL}: p=0.656, n=6$, LSD; $30 \mu \mathrm{g} / \mathrm{mL}: p=0.881$, $n=6, \mathrm{LSD})$.

As mentioned above, the relative increase in CGRP release after stimulation with MO or Caps was not strictly dose-dependent for the pre-treatment with petasin extract and isopetasin, but both resulted in a decreased CGRP release compared to pre-preatment with the vehicle ethanol. The CGRP release after stimulation with MO ranged from approximately half (doses 3, 10 and $30 \mu \mathrm{g} / \mathrm{mL}$ ) to about $15 \%$ for $100 \mu \mathrm{g} / \mathrm{mL}$ of petasins, similarly after stimulation with Caps (Table 7). CGRP levels after pre-treatment with isopetasin were in the same range except for the low dose of $3 \mu \mathrm{g} / \mathrm{mL}$, which was not followed by a reduction in CGRP release upon stimulation with Caps.

Therefore, petasins and isopetasin seem to have almost similar quantitative effects on the reduction in CGRP release. The stronger effect after $3 \mu \mathrm{g} / \mathrm{mL}$ petasins may be due to other components contained in butterbur root extract.

\section{Trigeminal ganglion}

Also for trigeminal ganglia, effects were compared after stimulating steps with $\mathrm{MO}$ and Caps. Univariate ANOVA did neither indicate significant differences after stimulation with MO nor with Caps between the petasin and isopetasin group (normalized data, $\mathrm{MO}: \mathrm{F}_{1,30}=1.17$, $p=0.29$; Caps: $\left.\mathrm{F}_{1,29}=1.59, p=0.22\right)$ as well as between the respective concentrations (normalized data, MO: $\mathrm{F}_{2,30}=0.17, p=0.85$; Caps: $\left.\mathrm{F}_{2,29}=0.67, p=0.52\right)$. The LSD post hoc test revealed that stimulation with $\mathrm{MO}$ did not cause significant differences between the respective doses of the petasin and isopetasin group (3 $\mu \mathrm{g} /$ $\mathrm{mL}: p=0.196 ; 10 \mu \mathrm{g} / \mathrm{mL}: p=0.511 ; 30 \mu \mathrm{g} / \mathrm{mL}: p=0.962$; $n=6$ for each concentration, LSD). However, stimulation with Caps caused significant differences for $3 \mu \mathrm{g} /$ $\mathrm{mL}(p=0.037, n=6$, LSD; $10 \mu \mathrm{g} / \mathrm{mL}: p=0.507, n=5$, LSD; $30 \mu \mathrm{g} / \mathrm{mL}: p=0.507, n=6$, LSD).

As mentioned above, in trigeminal ganglia the relative release of CGRP was again not strictly dose-dependent after previous incubation with both petasin extract and isopetasin. For the doses 10 and $30 \mu \mathrm{g} / \mathrm{mL}$, CGRP release was in

Table 5 Trigeminal ganglia, different petasin concentrations. CGRP release in $\mathrm{pg} / \mathrm{ml}$, all values are means $\pm \mathrm{SEM},{ }^{*} p<0.05$

\begin{tabular}{|c|c|c|c|c|c|c|c|c|}
\hline & \multicolumn{8}{|c|}{ Concentration of petasins in butterbur root extract } \\
\hline & $3.0 \mu \mathrm{g} / \mathrm{ml}$ & $\mathrm{p}$ (serial samples) & $10 \mu \mathrm{g} / \mathrm{ml}$ & p (serial samples) & $30 \mu \mathrm{g} / \mathrm{ml}$ & p (serial samples) & $100 \mu \mathrm{g} / \mathrm{ml}$ & $\mathrm{p}$ (serial samples) \\
\hline $\mathrm{n}$ & 6 & & 6 & & 6 & & 6 & \\
\hline SIF & $40.2 \pm 3.2$ & & $35.8 \pm 2.9$ & & $45.5 \pm 16.4$ & & $42.2 \pm 2.4$ & \\
\hline SIF & $48.3 \pm 4.6$ & 0.855 & $33.1 \pm 4.3$ & 0.951 & $44.5 \pm 11.6$ & 0.982 & $61.3 \pm 10.9$ & 0.668 \\
\hline MO $5 \times 10^{-4} \mathrm{M}$ & $251.5 \pm 66.9^{*}$ & $<0.001$ & $218.7 \pm 51.6^{*}$ & $<0.001$ & $212.0 \pm 24.9^{*}$ & $<0.001$ & $191.8 \pm 69.6^{*}$ & 0.004 \\
\hline SIF & $102.9 \pm 4.1^{*}$ & 0.001 & $106.0 \pm 14.0^{*}$ & 0.012 & $94.6 \pm 8.0 *$ & 0.009 & $78.8 \pm 10.5^{*}$ & 0.012 \\
\hline Caps $5 \times 10^{-7} \mathrm{M}$ & $212.1 \pm 35.7^{*}$ & 0.015 & $322.8 \pm 81.9 *$ & $<0.001$ & $338.8 \pm 47.7 *$ & $<0.001$ & $110.4 \pm 13.3$ & 0.477 \\
\hline
\end{tabular}


Table 6 Trigeminal ganglia, different isopetasin concentrations. CGRP release in $\mathrm{pg} / \mathrm{ml}$, all values are means \pm SEM, ${ }^{*} p<0.05$

\begin{tabular}{|c|c|c|c|c|c|c|}
\hline & \multicolumn{6}{|c|}{ Isopetasin concentration } \\
\hline & $3.0 \mu \mathrm{g} / \mathrm{ml}$ & $\mathrm{p}$ (serial samples) & $10 \mu \mathrm{g} / \mathrm{ml}$ & $\mathrm{p}$ (serial samples) & $30 \mu \mathrm{g} / \mathrm{ml}$ & $\mathrm{p}$ (serial samples) \\
\hline $\mathrm{n}$ & 6 & & 6 & & 6 & \\
\hline SIF & $75.8 \pm 24.1$ & & $28.0 \pm 4.4$ & & $34.5 \pm 3.5$ & \\
\hline SIF & $46.9 \pm 6.2$ & 0.515 & $27.2 \pm 3.6$ & 0.969 & $35.8 \pm 4.4$ & 0.976 \\
\hline MO $5 \times 10^{-4} \mathrm{M}$ & $370.4 \pm 68.5^{*}$ & $<0.001$ & $195.3 \pm 37.0^{*}$ & $<0.001$ & $221.2 \pm 33.6^{*}$ & $<0.001$ \\
\hline SIF & $129.0 \pm 11.4^{*}$ & $<0.001$ & $82.4 \pm 17.5^{*}$ & 0.012 & $83.6 \pm 9.2^{*}$ & 0.002 \\
\hline Caps $5 \times 10^{-7} \mathrm{M}$ & $479.1 \pm 65.7 *$ & $<0.001$ & $303.1 \pm 59.7^{*}$ & $<0.001$ & $272.5 \pm 62.6^{*}$ & $<0.001$ \\
\hline
\end{tabular}

the same range with a reduction by one third, approximately, compared to vehicle. The lowest increase in CGRP release was again measured after a dose of $100 \mu \mathrm{g} / \mathrm{mL}$ of petasins resulting in a CGRP release of less than 50\% after stimulation with MO and less than 20\% after Caps, respectively, compared to vehicle. Interestingly, the reduction of CGRP released from trigeminal ganglia after pre-incubation with $3 \mu \mathrm{g} / \mathrm{mL}$ of isopetasin was lower than after pre-treatment with petasins in the extract (see Table 8).

In summary, in trigeminal ganglia, petasins and isopetasin seem to have almost similar quantitative effects on the CGRP release. The stronger effect after $3 \mu \mathrm{g} / \mathrm{mL}$ petasins may be due to other components contained in butterbur root extract.

Butterbur root extract: effects in wild type, TRPV1-/- and TRPA1-/- mice

Wild type C57 BL/6 mice were compared to C57 BL/6 mice with functionally knocked out TRPA1 or TRPV1 receptors regarding the effect of pre-incubation with butterbur root extract on CGRP release. This effect was tested with a concentration of $30 \mu \mathrm{g} / \mathrm{mL}$ of petasins in butterbur root extract (solved in ethanol). Raw data with deviations are displayed in Tables 9, 10.

\section{Dura mater, basal CGRP release}

For all C57 BL/6 mice $(n=24)$, the basal CGRP release from the dura mater encephali after two 5-min washing steps with SIF was $19.7 \pm 1.6 \mathrm{pg} / \mathrm{mL}$.

\section{Dura mater, stimulated CGRP release}

Repeated measures ANOVA indicated significant differences after stimulation steps between the serial samples (raw data, $\mathrm{F}_{4,84}=123.57, p<0.0001$ ). For wild type C57 $\mathrm{BL} / 6$, significantly increased CGRP rates could be recorded after stimulation steps with $\mathrm{MO}(3.7$-fold) and Caps (12.1-fold) (MO: $p=0.0006, n=8$, LSD; Caps: $p<$ $0.0001, n=8$, LSD). TRPA1 receptor knocked out mice did not show significantly elevated CGRP release (1.3fold) after stimulation with MO ( $p=0.574, n=8$, LSD), while the CGRP release after stimulation with Caps was
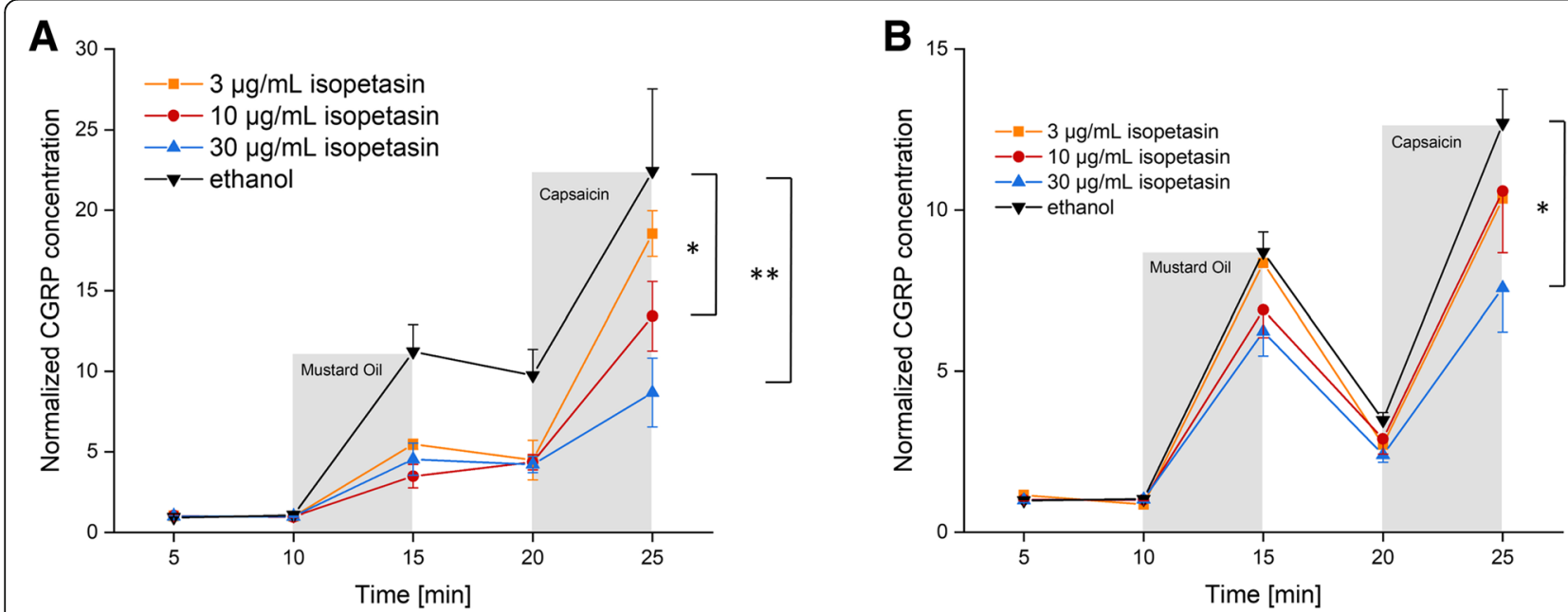

Fig. 2 a Dura mater, rat. b Trigeminal ganglion, rat. Normalized CGRP release after pre-incubation with isopetasin concentrations $(3,10,30 \mu \mathrm{g} / \mathrm{mL}$, $n=6$ each) compared to pre-incubation with ethanol $(n=12)$ for $1 \mathrm{~h}$. Stimulation steps with $5 \times 10^{-4} \mathrm{M}$ mustard oil (minutes $\left.10-15\right)$ or $5 \times 10^{-7}$ M capsaicin (minutes 20-25); other steps with SIF incubation (minutes 5-10 and 15-20); ${ }^{*} p<0.05,{ }^{* *} p<0.01$ 
Table 7 Dura mater encephali, Normalized data, Relative increase of CGRP after stimulation with Mustard Oil/Capsaicin. tdose of petasin/isopetasin, +vehicle (ethanol)

\begin{tabular}{|c|c|c|c|c|c|c|c|c|}
\hline & \multicolumn{4}{|c|}{ Petasin (in butterbur root extract) } & \multicolumn{4}{|l|}{ Isopetasin } \\
\hline & Mustard Oil & & Capsaicin & & Mustard Oil & & Capsaicin & \\
\hline Dose $/ \mu \mathrm{g} / \mathrm{mL}^{+}$ & means \pm SEM & $\%$ of vehicle & means \pm SEM & $\%$ of vehicle & means \pm SEM & $\%$ of vehicle & means $\pm S E M$ & $\%$ of vehicle \\
\hline $0^{+}$ & $9.9 \pm 1.8$ & 100.0 & $18.2 \pm 4.0$ & 100.0 & $9.9 \pm 1.8$ & 100.0 & $18.2 \pm 4.0$ & 100.0 \\
\hline 3 & $4.5 \pm 0.6$ & 45.4 & $7.9 \pm 1.0$ & 43.4 & $5.5 \pm 0.3$ & 55.6 & $18.6 \pm 1.4$ & 102.2 \\
\hline 10 & $5.6 \pm 0.8$ & 56.6 & $12.2 \pm 2.5$ & 67.0 & $3.5 \pm 0.7$ & 35.4 & $13.4 \pm 2.2$ & 73.6 \\
\hline 30 & $3.7 \pm 0.5$ & 37.4 & $9.1 \pm 1.0$ & 50.0 & $4.5 \pm 1.0$ & 45.5 & $8.7 \pm 2.1$ & 47.8 \\
\hline 100 & $1.3 \pm 0.1$ & 13.1 & $2.9 \pm 0.3$ & 15.9 & --- & --- & --- & --- \\
\hline
\end{tabular}

increased to 11.5 -fold ( $p<0.0001, n=8$, LSD). The dura mater of TRPV1 receptor knocked out mice was first stimulated with the TRPV1 receptor agonist Caps resulting in a slightly decreased (0.8-fold) CGRP level $(p=$ $0.929, n=8$, LSD). Stimulation with MO evoked a significantly increased CGRP release (4.0-fold) $(p=0.0001$, $n=8$, LSD) (Fig. 3a).

After stimulation steps, univariate ANOVA indicated significant differences between wild type, TRPA1 knocked out (ko) and TRPV1 ko receptor mice (normalized data, $\mathrm{MO}: \mathrm{F}_{2,21}=13.09, p=0.0002$; Caps: $\mathrm{MO}$ : $\left.\mathrm{F}_{2,21}=16.59, p<0.0001\right)$. LSD post hoc test revealed significant differences between TRPA1 knocked out mice and the two other groups, respectively, after stimulation with MO (wild type: $p=0.0004, n=8$; TRPV1 ko: $p=$ 0.0001, $n=8$, LSD), as well as between TRPV1 knocked out mice and the two other groups after stimulation with Caps (wild type: $p<0.0001, n=8$; TRPA1 ko: $p<0.0001$, $n=8$, LSD) (Fig. 3b).

\section{Trigeminal ganglion, basal CGRP release}

For all C57 BL/6 mice $(n=23)$, the basal CGRP release from trigeminal ganglia after two $5 \mathrm{~min}$ washing steps with SIF was $19.3 \pm 2.8 \mathrm{pg} / \mathrm{mL}$.

\section{Trigeminal ganglion, stimulated CGRP release}

Repeated measures ANOVA indicated significant differences after stimulation steps between the serial samples (raw data, $\mathrm{F}_{4,80}=55.62, p<0.0001$ ). For wild type C57 BL/
6, significantly increased CGRP rates could be recorded after stimulation steps with MI (6.5-fold) and Caps (13.9fold) (MO: $p<0.0001, n=8$, LSD; Caps: $p<0.0001, n=8$, LSD). TRPA1 receptor knocked out mice did not show significantly elevated CGRP release (1.2-fold) after stimulation with $\mathrm{MO}(p=0.959, n=8, \mathrm{LSD})$, while CGRP response after stimulation with Caps significantly (12.4-fold) increased ( $p<0.0001, n=8$, LSD). TG of TRPV1 receptor knocked out mice were first stimulated with the TRPV1 receptor agonist Caps resulting in a slightly increased CGRP level (2.2-fold) ( $p=0.891, n=7$, LSD). Stimulation with $\mathrm{MO}$ was followed by significantly elevated CGRP release (19.4-fold) ( $p=0.004, n=7$, LSD) (Fig. 3c).

After stimulation steps, univariate ANOVA indicated significant differences between wild type, TRPA1 knocked out and TRPV1 knocked out receptor mice (normalized data, MO: $\mathrm{F}_{2,18}=10.09, p=0.001$; Caps: $\left.\mathrm{F}_{2,18}=5.46, p=0.01\right)$. LSD post hoc test revealed significant differences between TRPV1 knocked out mice and the two other groups, respectively, after stimulation with MO (wild type: $p=0.008, n=8$; TRPA1 ko: $p=0.0003$, $n=8$, LSD), as well as between TRPV1 knocked out mice and the two other groups after stimulation with Caps (wild type: $p=0.048, n=8$; TRPA1 ko: $p=0.004$, $n=8$; LSD) (Fig. 3d).

\section{Discussion}

Our results suggest that petasins in butterbur root extract as well as isopetasin have an inhibiting effect on the TRPV1-

Table 8 Trigeminal ganglia, Normalized data, Relative increase of CGRP after stimulation with Mustard Oil/Capsaicin. †dose of petasin/isopetasin, +vehicle (ethanol)

\begin{tabular}{|c|c|c|c|c|c|c|c|c|}
\hline & \multicolumn{4}{|c|}{ Petasin (in butterbur root extract) } & \multicolumn{4}{|l|}{ Isopetasin } \\
\hline & Mustard Oil & & Capsaicin & & Mustard Oil & & Capsaicin & \\
\hline Dose $/ \mu \mathrm{g} / \mathrm{mL}$ & means \pm SEM & $\%$ of vehicle & means \pm SEM & $\%$ of vehicle & means \pm SEM & $\%$ of vehicle & means \pm SEM & $\%$ of vehicle \\
\hline $0^{+}$ & $8.8 \pm 0.6$ & 100.0 & $12.5 \pm 1.3$ & 100.0 & $8.8 \pm 0.6$ & 100.0 & $12.5 \pm 1.3$ & 100.0 \\
\hline 3 & $5.6 \pm 1.4$ & 63.6 & $4.8 \pm 0.8$ & 38.4 & $8.4 \pm 2.3$ & 95.5 & $10.4 \pm 2.6$ & 83.2 \\
\hline 10 & $5.9 \pm 1.0$ & 67.0 & $8.8 \pm 1.5$ & 70.4 & $6.9 \pm 0.9$ & 78.4 & $10.6 \pm 1.9$ & 84.8 \\
\hline 30 & $6.1 \pm 1.0$ & 69.3 & $9.3 \pm 1.3$ & 74.4 & $6.2 \pm 0.8$ & 70.4 & $7.6 \pm 1.4$ & 60.8 \\
\hline 100 & $4.0 \pm 1.6$ & 45.4 & $2.4 \pm 0.5$ & 19.2 & --- & --- & --- & --- \\
\hline
\end{tabular}


Table 9 Dura mater encephali, CGRP release after pre-incubation with $30 \mu \mathrm{g} / \mathrm{mL}$ petasins in butterbur root extract. CGRP release in $\mathrm{pg} / \mathrm{mL}$, all values are means \pm SEM, ${ }^{*} p<0.05$

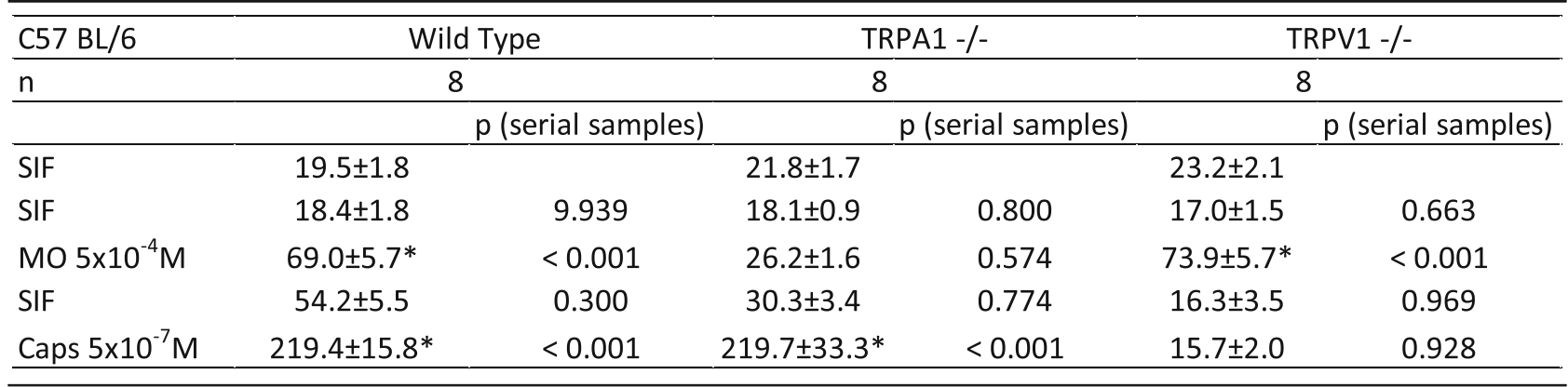

and TRPA1-mediated CGRP release. After pre-treatment with petasins, CGRP released from the dura mater and trigeminal ganglia was - partly significantly - reduced after stimulation with $\mathrm{MO}$ or Caps compared to pre-incubation with ethanol as vehicle. Pre-treatment with $100 \mu \mathrm{g} / \mathrm{mL}$ of petasins in butterbur root extract resulted in a nonsignificant CGRP release from both the dura mater and trigeminal ganglia compared with previous incubation steps.

For TRPA1 receptor channels, Benemei et al. [32] already reported a reduction of CGRP release from mouse dorsal spinal cord slices upon stimulation with MO after $30 \mathrm{~min}$ exposure to a high concentration of isopetasin $(300 \mu \mathrm{M})$. We confirmed these findings in peripheral tissues, the dura mater and trigeminal ganglia, even after treatment with lower concentrations of petasins. However, different to the findings of Benemei et al., who did not see an activation of TRPV1 channels expressed in HEK293 cells by isopetasin, we observed also a decrease in CGRP release upon stimulation of TRPV1 following pretreatment with petasins. The stimulating agent Caps is a specific and direct agonist of TRPV1 [14, 47] and, as we showed a significant reduction of the Caps-induced TRPV1 response, it is more than evident that TRPV1 is another site of action of petasins. Since it has been shown that TRPA1 and TRPV1 channels interact functionally undergoing reciprocal sensitization $[48,49]$, it seems possible that TRPV1 requires the presence of TRPA1 to respond effectively to petasins, which may be worth to be explored in further experiments. Immunohistochemically, TRPV1 receptor channels are found co-localized with CGRP-positive neurons $[10,11]$ which are probably of immense importance for the transduction and amplification of pain in the trigeminovascular system [50-52]. TRPV1 receptor channels are often co-expressed with TRPA1 receptor channels [12-14], and therefore, it is likely that both channels are affected simultaneously by petasins and act together in the trigeminovascular system.

Although there is no strict dose-dependency, we demonstrated that the effects of petasins generally increased at higher doses. Pre-treatment with $100 \mu \mathrm{g} / \mathrm{mL}$ petasin in the extract resulted in the most effective suppression of CGRP release from the dura mater and trigeminal ganglia. After stimulation with $\mathrm{MO}$ and Caps, CGRP was not significantly increased compared to previous incubation steps. In trend, effects of petasin in the extract and pure isopetasin were similar, however, isopetasin doses were investigated up to $30 \mu \mathrm{g} / \mathrm{mL}$ only. Therefore, further analysis of doses might be interesting: A dose of $100 \mu \mathrm{g} / \mathrm{mL}$ of isopetasin in comparison to $100 \mu \mathrm{g} / \mathrm{mL}$ of petasins in the extract as well as an additional dose testing in the range of $>30 \mu \mathrm{g} / \mathrm{mL}$ and $<100 \mu \mathrm{g} / \mathrm{mL}$ would probably allow more exact statements about the effectiveness of the respective doses.

Table 10 Trigeminal ganglia, CGRP release after pre-incubation with $30 \mu \mathrm{g} / \mathrm{mL}$ petasins in butterbur root extract. CGRP release in $\mathrm{pg} / \mathrm{mL}$, all values are means $\pm \mathrm{SEM},{ }^{*} p<0.05$

\begin{tabular}{|c|c|c|c|c|c|c|}
\hline $\mathrm{C} 57 \mathrm{BL} / 6$ & Wild Type & & TRPA1 -/- & & TRPV1 -/- & \\
\hline \multirow[t]{2}{*}{$n$} & 8 & & 8 & & 7 & \\
\hline & & erial samples) & & p (serial samples) & & p (serial samples) \\
\hline SIF & $36.4 \pm 3.9$ & & $16.9 \pm 2.5$ & & $8.5 \pm 1.7$ & \\
\hline SIF & $29.7 \pm 3.3$ & 0.834 & $18.3 \pm 3.5$ & 0.967 & $6.1 \pm 1.6$ & 0.942 \\
\hline MO $5 \times 10^{-4} \mathrm{M}$ & $220.3 \pm 32.7 *$ & $<0.001$ & $19.9 \pm 3.2$ & 0.959 & $106.9 \pm 16.7^{*}$ & 0.004 \\
\hline SIF & $70.5 \pm 6.4^{*}$ & $<0.001$ & $18.4 \pm 2.9$ & 0.961 & $6.3 \pm 0.8$ & 0.896 \\
\hline Caps $5 \times 10^{-7} \mathrm{M}$ & $450.3 \pm 62.3^{*}$ & $<0.001$ & $204.5 \pm 50.5^{*}$ & $<0.001$ & $10.8 \pm 1.9$ & 0.891 \\
\hline
\end{tabular}




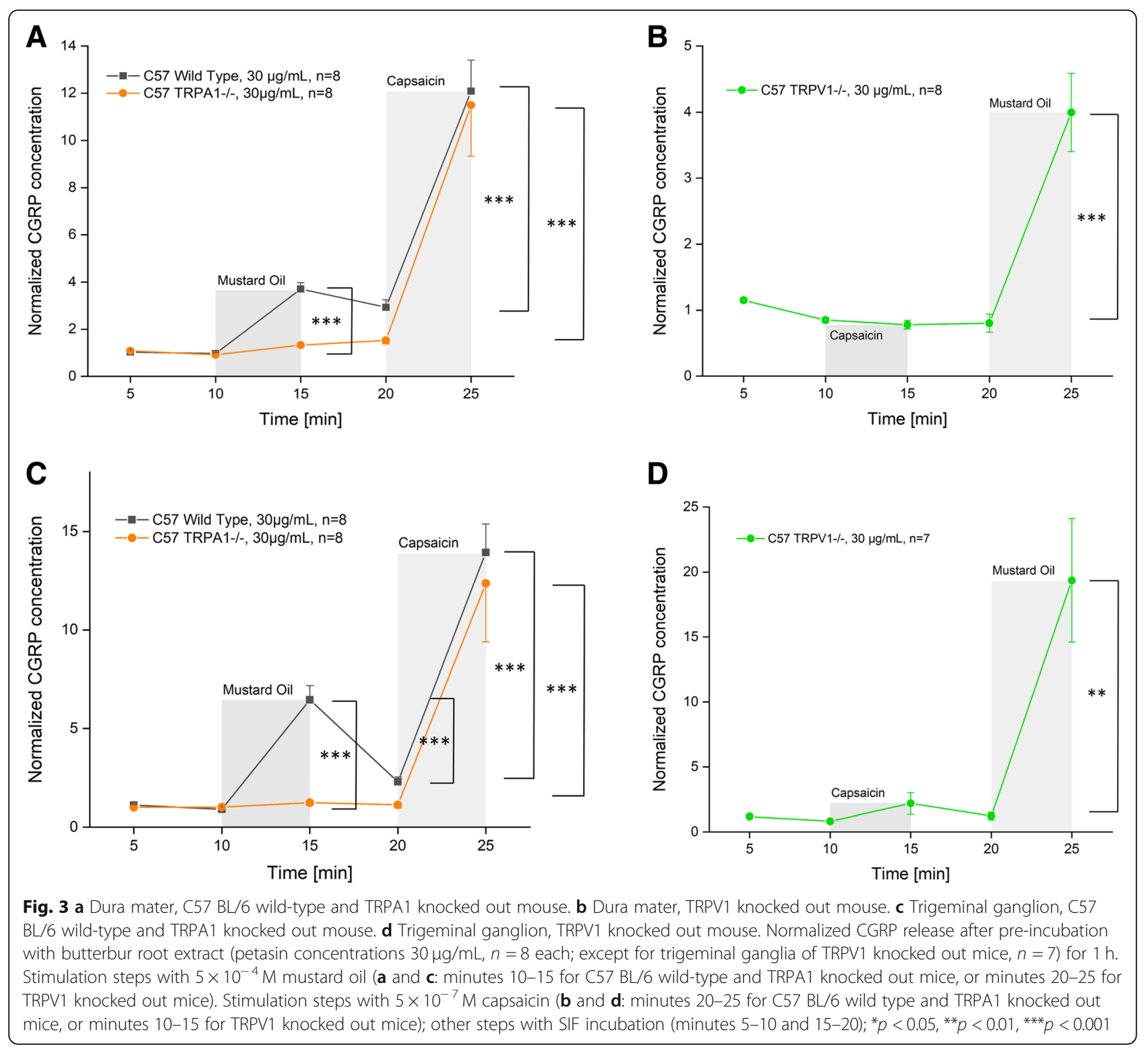

Interestingly, after pre-treatment with $3 \mu \mathrm{g} / \mathrm{mL}$ of petasins in the extract or isopetasin and stimulation with Caps, TRPV1 receptor channel activity was significantly different between the two substances. CGRP release after pre-incubation with $3 \mu \mathrm{g} / \mathrm{mL}$ of isopetasin and stimulation with Caps was significantly higher than after the same dose of petasins in butterbur root extract. This phenomenon is reported for this lowest concentration and after stimulation with Caps only. It is not very probable that the effect is based on different actions of petasin and isopetasin, as petasin converts into isopetasin spontaneously [32]. The difference is possibly due to other components contained in the extract, which might be without effect at higher doses of petasins. Possibly antinociceptive effects of TRPA1 receptor channels are more active after pre-treatment with petasins in butterbur root extract than after pure isopetasin. The effect of other components of butterbur root extract and their impact on TRP receptor channels might be an interesting subject of further investigation.

The experiments with functionally deleted TRP receptors have been controlled by wild type receptor configuration with pre-treatment of the same concentration of petasins in the extract. However, a control without preincubation with an active substance did not take place, and thus a comparison without pre-treatment is lacking. Nevertheless, our data suggest that the effect indeed exists according to the earlier dose finding experiments, in which we not only compared different doses but also controlled the effects by a pre-incubation with ethanol 
only. It is not surprising that the results of the experiments with functionally deleted TRP receptors indicate that receptor responses take place neither in the dura nor in TG of the animals with the respective functionally deleted TRP receptor channels. Nevertheless, the quantitative CGRP release after stimulation of TRPA1 receptors channels of TRPV1-/- mice compared with the CGRP release after stimulation of TRPA1 of wild type mice was almost identical in the dura. As we observed the same effect for TRPV1 receptor channels in TRPA1 -/- mice compared to wild type, a cooperative effect between the two TRP receptor channels is not evident. Adding to the discussion above, this might be due to a lack of functional synergism of these receptors in the dura possibly abolished by pre-treatment with petasins. Likewise, in trigeminal ganglia of TRPA1-/- mice compared to wild type, quantitative CGRP release after stimulation with Caps was in the same range, so that we suggest an inhibited synergism of the receptors there, too. However, the TRPA1 receptor response from trigeminal ganglia with functionally deleted TRPV1 receptor channels was three times higher (19.4-fold) in comparison to wild type (6.5-fold). Benemei et al. [32] suggest that isopetasin at lower concentrations $(100 \mu \mathrm{M})$ may act as a partial agonist of TRPA1 receptor channels resulting in an isopetasin-evoked CGRP release in TRPV1-positive neurons. Since CGRP release is calcium-dependent, and $\mathrm{Ca}^{2+}$-influx mediated by TRPV1 is not possible via these channels in TRPV1-/- mice, the influx is possibly solely mediated by activated TRPA1 receptor channels being permeable for calcium cations, too [14]. Thus, in trigeminal ganglia, a coexpression of TRP receptors may be of functional importance in an inverse way. A possible anti-nociceptive synergistic action after pre-treatment with petasins may be effective only if both, TRPV1 and TRPA1, receptor channels are intact. It might be that the main site of action of petasins in sensory neurons of trigeminal ganglia are TRPV1 receptor channels, and that TRPA1 effects are modulated by TRPV1, as discussed [48, 49]. Consequently, TRPV1 knocked out receptor channels might result in a pro-nociceptive effect of the still intact TRPA1 receptor channels, which have not been inactivated by petasins. The idea of an increased TRPA1 receptor response after treatment with petasins due to functionally deleted TRPV1 receptor channels is contradictory to previous findings of CGRP release experiments, in which stimulation with MO resulted in a lower TRPA1 response in TRPV1-/- mice [15]. However, this discrepancy might be again due to pretreatment with petasins.

As mentioned above, butterbur root extract is successfully used in migraine prophylaxis [20-22]. However, long-term effects of either petasins in the extract or pure isopetasin could not be taken into consideration in this work. The pre-incubation period lasted $1 \mathrm{~h}$ so that only a snapshot of possible effects has been made, and we must assume that a repeated long-term application leads to higher and stronger results. On the other hand, there may also be other components contained in the extract that may be effective after a regular and repeated exposition. As the structures of the ex vivo experiments performed in this work cannot be held viable over a longer period, a partly different method should be taken into consideration. In order to achieve an understanding of long-term effects and mechanisms, repeated in vivo application of petasins in the extract and isopetasin followed by an examination of the in vitro CGRP release in comparison to placebo or nocebo might be an interesting approach.

An issue, which could not be examined in the experimental rodent preparation, is the fact that the plant butterbur contains pyrrolizidines alkaloids (PAs) which are associated with hepatotoxicity $[34,53]$. The PAs of the plant's rhizome are non-toxic hydrophile $\mathrm{N}$-oxides, however, they are reduced by gut bacteria and subsequently resorbed as lipophile PAs. In the liver, oxidation via cytochrome P450 and further decomposition results in toxic and carcinogen PAs which may cause liver tumors [34, 54]. Therefore, it is important to remove the toxic constituents and to use a PA-free butterbur root extract for migraine prevention $[39,40]$.

\section{Conclusion}

In summary, this work shows that butterbur root extract with its active agents petasin and isopetasin possibly not only affects TRPA1 receptor channels but also TRPV1 resulting in decreased CGRP levels in a well-established ex vivo model. However, several ambiguities derive from the current findings: Future approaches could handle the question, if TRPA1 and TRPV1 are the only receptors involved in the site of action of petasins, and if there is an additional contribution of e.g. transient receptor potential melastatin type 8 (TRPM8) receptor channels. Furthermore, it is of considerable interest, which of the receptor channels is the main actor, and how cooperative effects within the TRP family mediate the action. Another subject are possible other active components of the extract that are of therapeutic relevance, and how a long-term treatment influences the results.

\footnotetext{
Abbreviations

AChE: Acetylcholinesterase; Caps: Capsaicin; CGRP: Calcitonin gene-related peptide; ko: Knocked out; MO: Mustard oil; PAs: Pyrrolizidines alkaloids; SIF: Synthetic interstitial fluid; TG: Trigeminal ganglion; TRPA1: Transient receptor potential ankyrin type 1; TRPM8: Transient receptor potential melastatin type 8; TRPV1: Transient receptor potential vanilloid type 1; VGCC: Voltage-gated $\mathrm{Ca}^{2+}$-channel
} 


\section{Acknowledgements}

We like to thank Ulrich Danesch (Weber \& Weber) for providing Petadolex৫ and experimental advice, Annette Kuhn for excellent technical assistance with the ELISA, Jana Schramm and Rainer Fischer for breeding the animals.

\section{Authors' contributions}

JKH performed the experiments, analyzed and interpreted the data, and wrote the manuscript, BV performed the experiments, KM supervised the project, designed the study, analyzed and interpreted the data, and wrote the manuscript. All authors read and approved the final manuscript. The first author performed this work for obtaining the degree "Dr. med." at the Friedrich-Alexander-University Erlangen-Nürnberg (FAU).

\section{Funding}

The study was supported in part by Weber \& Weber $\mathrm{GmbH}$, Inning, Germany. Open Access funding enabled and organized by Projekt DEAL.

\section{Availability of data and materials}

All data generated and analysed during this study are included in this article.

\section{Declarations}

\section{Ethics approval and consent to participate}

All experiments and procedures were carried out according to the German guidelines and regulations of the care and treatment of laboratory animals and the European Communities Council Directive of November 24, 1986 (86/ 609/EEC), amended September 22, 2010 (2010/63/EU).

\section{Consent for publication}

All authors agree with the manuscript in the present form.

\section{Competing interests}

The authors declare that they have no competing interests.

\section{Received: 28 January 2021 Accepted: 26 March 2021}

\section{Published online: 13 April 2021}

\section{References}

1. MacGregor EA (2017) Migraine. Ann Intern Med 166(7):Itc49-itc64 https:// doi.org/10.7326/aitc201704040

2. Dodick DW (2018) Migraine. Lancet 391(10127):1315-1330 https://doi.org/ 0.1016/S0140-6736(18)30478-1

3. Silberstein SD (2004) Migraine. Lancet 363(9406):381-391 https://doi.org/1 0.1016/S0140-6736(04)15440-8

4. Goadsby PJ, Holland PR, Martins-Oliveira M, Hoffmann J, Schankin C, Akerman S (2017) Pathophysiology of migraine: a disorder of sensory processing. Physiol Rev 97(2):553-622 https://doi.org/10.1152/physrev.00034.2015

5. Goadsby PJ, Holland PR (2019) An update: pathophysiology of migraine. Neurol Clin 37(4):651-671 https://doi.org/10.1016/j.ncl.2019.07.008

6. Noseda R, Burstein R (2013) Migraine pathophysiology: anatomy of the trigeminovascular pathway and associated neurological symptoms, cortical spreading depression, sensitization, and modulation of pain. Pain 154(Supplement 1):S44-S53. https://doi.org/10.1016/j.pain.2013.07.021

7. Burstein R, Noseda R, Borsook D (2015) Migraine: multiple processes, complex pathophysiology. J Neurosci 35(17):6619-6629. https://doi.org/10.1 523/JNEUROSCI.0373-15.2015

8. Ashina M, Hansen J, Do T et al (2019) Migraine and the trigeminovascular system-40 years and counting. Lancet Neurol 18(8):795-804. https://doi. org/10.1016/S1474-4422(19)30185-1

9. lyengar S, Johnson KW, Ossipov MH, Aurora SK (2019) CGRP and the trigeminal system in migraine. Headache 59(5):659-681 https://doi.org/1 $0.1111 /$ head. 13529

10. Price TJ, Flores CM (2007) Critical evaluation of the colocalization between calcitonin gene-related peptide, substance $P$, transient receptor potential vanilloid subfamily type 1 immunoreactivities, and isolectin B4 binding in primary afferent neurons of the rat and mouse. J Pain 8(3):263-272 https:// doi.org/10.1016/j.jpain.2006.09.005

11. Dux M, Rosta J, Messlinger K (2020) TRP channels in the focus of trigeminal nociceptor sensitization contributing to primary headaches. Int J Mol Sci 21(1):342. https://doi.org/10.3390/ijms21010342
12. Bautista $D$, Jordt $S$, Nikai T et al (2006) TRPA1 mediates the inflammatory actions of environmental irritants and proalgesic agents. Cell 124(6):12691282. https://doi.org/10.1016/j.cel.2006.02.23

13. Bautista D, Pellegrino M, Tsunzaki M (2013) TRPA1: a gatekeeper for inflammation. Annu Rev Physiol 75(1):181-200. https://doi.org/10.1146/a nnurev-physiol-030212-183811

14. Julius D (2013) TRP channels and pain. Annu Rev Cell Dev Biol 29(1):355384 https://doi.org/10.1146/annurev-cellbio-101011-155833

15. Denner AC, Vogler B, Messlinger K, de Col R (2017) Role of transient receptor potential ankyrin 1 receptors in rodent models of meningeal nociception experiments in vitro. Eur J Pain 21(5):843-854 https://doi.org/10.1002/ejp.986

16. Fischer MJ, Balasuriya D, Jeggle $P$ et al (2014) Direct evidence for functional TRPV1/TRPA1 heteromers. Pflugers Arch 466(12):2229-2241 https://doi.org/1 0.1007/s00424-014-1497-z

17. Andersson DA, Gentry C, Alenmyr L, Killander D, Lewis SE, Andersson A Bucher B, Galzi JL, Sterner O, Bevan S, Högestätt ED, Zygmunt PM (2011) TRPA1 mediates spinal antinociception induced by acetaminophen and the cannabinoid $\Delta$ (9)-tetrahydrocannabiorcol. Nat Commun 2(1):551. https:// doi.org/10.1038/ncomms1559

18. Teicher C, De Col R, Messlinger K (2017) Hydrogen sulfide mediating both excitatory and inhibitory effects in a rat model of meningeal nociception and headache generation. Front Neurol 8:336 https://doi.org/10.3389/fneur.2017.00336

19. Edmeads J (1999) History of migraine treatment. Can J Clin Pharmacol 6(Suppl A):5a-8a

20. Grossmann W, Schmidramsl H (2001) An extract of Petasites hybridus is effective in the prophylaxis of migraine. Altern Med Rev 6(3):303-310

21. Diener HC, Rahlfs WW, Danesch U (2004) The first placebo-controlled trial of a special butterbur root extract for the prevention of migraine: reanalysis of efficacy criteria. Eur Neurol 51(2):89-97 https://doi.org/10.1159/000076535

22. Lipton RB, Göbel H, Einhäupl KM et al (2004) Petasites hybridus root (butterbur) is an effective preventive treatment for migraine. Neurology 63(12):2240. https://doi.org/10.1212/01.WNL.0000147290.68260.11-2244

23. Messlinger K, Hanesch U, Baumgärtel M et al (1993) Innervation of the dura mater encephali of cat and rat: ultrastructure and calcitonin gene-related peptide-like and substance P-like immunoreactivity. Anat Embryol 188(3): 219-237 https://doi.org/10.1007/BF00188214

24. Edvinsson L, Ekman R, Jansen I, McCulloch J, Uddman R (1987) Calcitonin gene-related peptide and cerebral blood vessels: distribution and vasomotor effects. J Cereb Blood Flow Metab 7(6):720-728 https://doi.org/1 $0.1038 / j c b f m .1987 .126$

25. Lennerz JK, Rühle V, Ceppa EP, Neuhuber WL, Bunnett NW, Grady EF, Messlinger K (2008) Calcitonin receptor-like receptor (CLR), receptor activitymodifying protein 1 (RAMP1), and calcitonin gene-related peptide (CGRP) immunoreactivity in the rat trigeminovascular system: differences between peripheral and central CGRP receptor distribution. J Comp Neurol 507(3): 1277-1299 https://doi.org/10.1002/cne.21607

26. Eftekhari S, Salvatore C, Calamari A et al (2010) Differential distribution of calcitonin gene-related peptide and its receptor components in the human trigeminal ganglion. Neuroscience 169(2):683-696. https://doi.org/10.1016/j. neuroscience.2010.05.016

27. Eftekhari S, Edvinsson L (2011) Calcitonin gene-related peptide (CGRP) and its receptor components in human and rat spinal trigeminal nucleus and spinal cord at C1-level. BMC Neurosci 12(1):112 https:/doi.org/10.1186/1471-2202-12-112

28. Zaidi M, Breimer LH, Maclntyre I (1987) Biology of peptides from the calcitonin genes. Q J Exp Physiol 72(4):371-408 https://doi.org/10.1113/ expphysiol.1987.sp003084

29. Lundberg J, Franco-Cereceda A, Alving K et al (1992) Release of calcitonin gene-related peptide from sensory neurons. Ann N Y Acad Sci 657(1 Calcitonin Ge):187-193. https://doi.org/10.1111/j.1749-6632.1992.tb22767.x

30. Edvinsson L, Haanes KA, Warfvinge K, Krause DN (2018) CGRP as the target of new migraine therapies - successful translation from bench to clinic. Nat Rev Neurol 14(6):338-350 https://doi.org/10.1038/s41582-018-0003-1

31. Messlinger $K$ (2018) The big CGRP flood - sources, sinks and signalling sites in the trigeminovascular system. J Headache Pain 19(1):22 https://doi.org/1 0.1186/s10194-018-0848-0

32. Benemei S, De Logu F, Li Puma S et al (2017) The anti-migraine component of butterbur extracts, isopetasin, desensitizes peptidergic nociceptors by acting on TRPA1 cation channel. Br J Pharmacol 174(17):2897-2911. https:// doi.org/10.1111/bph.13917

33. Slavin M, Bourguignon J, Jackson K, Orciga MA (2016) Impact of food components on in vitro calcitonin gene-related peptide secretion-a 
potential mechanism for dietary influence on migraine. Nutrients 8(7):406 https://doi.org/10.3390/nu8070406

34. Kälin P (2003) Gemeine pestwurz (petasites hybridus) - portrait einer arzneipflanze. Complement Med Res 10(suppl 1):41-44 https:/doi.org/10.1159/000071691

35. Bucher K (1951) Über ein antispastisches prinzip in petasites officinals moench. Arch Exper Path u Pharmakol 213(1):69-71. https//doi.org/10.1007/BF02432740

36. Bauer H, Kuehne P (1986) Therapie von Harnleiterkoliken mit einem neuen Spasmoanalgetikum. Therapiewoche 36:3756-3759

37. Schapowal A (2002) Randomised controlled trial of butterbur and cetirizine for treating seasonal allergic rhinitis. BMJ 324(7330):144. https://doi.org/1 $0.1136 / \mathrm{bmj} .324 .7330 .144-146$

38. Schapowal A (2005) Treating intermittent allergic rhinitis: a prospective, randomized, placebo and antihistamine-controlled study of butterbur extract Ze 339. Phytother Res 19(6):530-537 https://doi.org/10.1002/ptr.1705

39. Aydin A, Zerbes V, Parlar $\mathrm{H}$ et al (2013) The medical plant butterbur (Petasites): a analytical and physiological (re)view. J Pharm Biomed Anal 75: 220-229 https://doi.org/10.1016/j.jpba.2012.11.028

40. Danesch U, Rittinghausen R (2003) Safety of a patented special butterbur root extract for migraine prevention. Headache 43(1):76-78 https://doi.org/1 0.1046/j.1526-4610.2003.03015.X

41. Thomet OAR, Wiesmann UN, Blaser K, Simon HU (2001) Differential inhibition of inflammatory effector functions by petasin, isopetasin and neopetasin in human eosinophils. Clin Exp Allergy 31(8):1310-1320 https:// doi.org/10.1046/j.1365-2222.2001.01158.x

42. Wang GJ, Shum AY, Lin YL, Liao JF, Wu XC, Ren J, Chen CF (2001) Calcium channel blockade in vascular smooth muscle cells: major hypotensive mechanism of S-petasin, a hypotensive sesquiterpene from Petasites formosanus. J Pharmacol Exp Ther 297(1):240-246

43. Wang GJ, Wu XC, Lin YL, Ren J, Shum AYC, Wu YY, Chen CF (2002) Ca2+ channel blocking effect of iso-S-petasin in rat aortic smooth muscle cells. Eur J Pharmacol 445(3):239-245 https://doi.org/10.1016/50014-2999(02)01764-8

44. Wang GJ, Liao JF, Hintz KK, Shi CC, Chen CF, Chen WP, Su MJ, Lin YL, Ren J (2004) Calcium-antagonizing activity of S-petasin, a hypotensive sesquiterpene from Petasites formosanus, on inotropic and chronotropic responses in isolated rat atria and cardiac myocytes. Naunyn Schmiedeberg's Arch Pharmacol 369(3):322-329 https:/doi.org/10.1007/s00210-003-0863-8

45. Horak S, Koschak A, Stuppner H et al (2009) Use-dependent block of voltage-gated Cav2.1 Ca2+ channels by petasins and eudesmol isomers. J Pharmacol Exp Ther 330(1):220 https://doi.org/10.1124/jpet.109.151183

46. Ko WC, Lei CB, Lin YL, Chen CF (2001) Mechanisms of relaxant action of S-petasin and S-isopetasin, sesquiterpenes of petasites formosanus, in isolated guinea pig trachea. Planta Med 67(3):224-229 https://doi.org/10.1055/s-2001-11991

47. Patapoutian A, Tate S, Woolf CJ (2009) Transient receptor potential channels: targeting pain at the source. Nat Rev Drug Discov 8(1):55-68 https://doi.org/10.1038/nrd2757

48. Salas MM, Hargreaves KM, Akopian AN (2009) TRPA1-mediated responses in trigeminal sensory neurons: interaction between TRPA1 and TRPV1. Eur J Neurosci 29(8):1568-1578 https://doi.org/10.1111/j.1460-9568.2009.06702.x

49. Patil MJ, Salas M, Bialuhin S, Boyd JT, Jeske NA, Akopian AN (2020) Sensitization of small-diameter sensory neurons is controlled by TRPV1 and TRPA1 association. FASEB J 34(1):287-302 https://doi.org/10.1096/fj.201902026R

50. Fernandes E, Fernandes M, Keeble J (2012) The functions of TRPA1 and TRPV1: moving away from sensory nerves. Br J Pharmacol 166(2):510-521 https://doi.org/10.1111/j.1476-5381.2012.01851.x

51. Benemei S, Fusi C, Trevisan G, Geppetti P (2014) The TRPA1 channel in migraine mechanism and treatment. Br J Pharmacol 171(10):2552-2567. https://doi.org/10.1111/bph.12512

52. Dussor G, Cao Y-Q (2016) TRPM8 and migraine. Headache 56(9):1406-1417 https://doi.org/10.1111/head.12948

53. Mauskop A (2013) Evidence-based guideline update: NSAIDs and other complementary treatments for episodic migraine prevention in adults: report of the Quality Standards Subcommittee of the American Academy of Neurology and the American Headache Society. Neurology 80(9):868. https://doi.org/10.1212/WNL.0b013e318287d94b-869

54. Habs M, Habs H, Forth W (1991) Kanzerogene naturprodukte: risikobewertung pyrrolizidinhaltiger arzneistoffe. Dtsch Arztebl 88(41):A-3425

\section{Publisher's Note}

Springer Nature remains neutral with regard to jurisdictional claims in published maps and institutional affiliations.

\section{Ready to submit your research? Choose BMC and benefit from:}

- fast, convenient online submission

- thorough peer review by experienced researchers in your field

- rapid publication on acceptance

- support for research data, including large and complex data types

- gold Open Access which fosters wider collaboration and increased citations

- maximum visibility for your research: over $100 \mathrm{M}$ website views per year

At $\mathrm{BMC}$, research is always in progress.

Learn more biomedcentral.com/submissions 